\title{
GREEN BONDS AS A SOURCE OF FINANCING PRO-ENVIRONMENTAL ACTIONS IN POLAND
}

\author{
Dagmara Hajdys \\ The Faculty of Economics and Sociology, University of Lodz \\ ORCID: https://orcid.org/0000-0001-6371-5423
}

\begin{abstract}
Climate changes and progressing environmental pollution enforce undertaking various actions of the global range. Implementation and execution of pro-environmental programs require appropriate financing. In 2007 a new instrument, referred to as green bonds, appeared in the market. Since that, a systematic and dynamic development of this segment of capital market has been observed. The development takes place in terms of values, a number of instruments and a number of issuers. In 2016 a pioneering issuance of green bonds issued by the Polish government appeared in the market.

The objective of the study is to characterize green bonds issued by the Polish government to finance pro-environmental actions against the background of the global green market of debt securities. The hypothesis accepted in the study stated that the development of green bonds in Poland is determined by the development of the global green market of debt securities and is a response to a need for intensification of expenditure on pro-environmental programs.
\end{abstract}

Keywords: green bonds, pro-environmental investments, climate change, global market.

JEL Class: G1, G18, H63, Q54. 


\section{INTRODUCTION}

Recently not a day goes by without informing the public about climate anomalies. Environmental protection and a need for changes of current behavior directed at reducing consumerism have dominated a discussion in scientific, social and political terms. The places where such discussions are extremely loud are forums of international institutions (the UN, the European Commission) along with regular conferences such as the Climate Summit or the Economic Forum. The face of the discussion that took place in 2019 was a Swedish teenager, Greta Thunberg who expressively shows her disapproval towards a lack of efficient actions undertaken by global decision-makers to counteract the symptoms of ,approaching climate catastrophe".

Dangerously deepening ecological crisis manifested by, among others, an increase in air and water temperature together with all resulting devastating environmental and social consequences, require immediate, correlated actions of political and legal-economic nature. However, it must be kept in mind that all system changes generate additional, often very high costs. Budget constraints are the main limitations of implementation of programs connected with climate changes. An instrument breaking this state of affairs can be green bonds. Over the last twelve years there has been a dynamic development of that segment of capital market. The issuers include financial institutions, enterprises, and over the last three years state authorities also joined the group with their green bonds.

The objective of the study is to characterize green bonds issued by the Polish government to finance pro-environmental actions against the background of the global green market of debt securities. The hypothesis accepted in the study stated that the development of green bonds in Poland is determined by the development of the global green market of debt securities and is a response to a need for intensification of expenditure on pro-environmental programs.

The presented study was based on the economic literature and publications concerning green bond market of the following institutions: the World Bank, OECD, International Capital Market Association, Climate Bond Initiative and the Ministry of Finance.

\section{SPECIFICITY OF GREEN BONDS}

Green bonds are one of the latest innovations in financing pro-environmental projects. They are a typical debt security meeting standards of bonds whose distinctive feature is their accompanying purpose [Gatti and Florio 2018: 208].

Green bonds are in the literature referred to as debt securities issued by governments, international financial institutions, banks, enterprises in order to 
obtain capital to finance (or refinance) ventures contributing to the improvement of natural environment, especially to the development of low-carbon economy and economy resistant to climate changes [Kaminker 2012: 34, access 8.01.2020]. According to the Climate Bond Initiative (CBI), an institution recommending standards of green bond issue, funds obtained that way can be allocated to projects connected with [Climate Bond Initiative, access 8.01.2020; Pawłowski 2019: 164-165; International Capital Market Association, Green Bond Principles 2017: 4, access 8.01.2020; Banga 2019: 1; Laskowska 2019: 112; Wiśniewski and Zieliński 2019: 91]:

1) renewable energy - investments in solar, wind, water, bioenergy and geothermal energy, with focus on expenditure on infrastructure, production, distribution and warehousing;

2) energy efficiency - comprising building and modernization of green residential objects (buildings) and commercial ones, designing and implementation of energy-efficient products, processes and technologies, waste heat recovery along with reduction in greenhouse gases;

3) low-emission transport - electric, hybrid, public, rail, non-motorized, multi-modal, transport, infrastructure for ecological vehicles and reduction in emission of harmful substances, building national and local rail systems, fast bus transit, cycle transport, aviation biofuels;

4) sustainable water management - systems of adaptation of precipitation water, purification and recycling of water resources, reducing economic vulnerability to volatility of precipitation;

5) waste management, recycling and pollution control - actions in the area of close-circuit economy directed at reducing energy usage and emission of greenhouse gases;

6) sustainable agriculture and forestry - sustainable animal husbandry, climate-friendly means of agricultural production such as biological plant protection or drip irrigation, sustainable fishery and aquaculture, environmentally sustainable forestry, including afforestation and reforestation or protection or restoration of natural landscape;

7) infrastructure resistant to climate changes, mainly in terms of weather anomalies.

The analysis of available literature indicates that financing pro-environmental actions with debt securities is interchangeably referred to as green bonds, environmental bonds and climate bonds. The boundary between these terms is not explicit, and diverse names are mostly connected with an issuance purpose.

Green and environmental bonds serve to collect capital in order to finance ventures directed at environment protection, whereas climate bonds additionally support projects that aim to reduce emissions of greenhouse gases and adjust the economy to climate changes [Kerste et al. 2011: 196; Nordic Perspectives... 2011: 
47; Więckowska 2013: 455; Kidney and Boulle 2015: 582]. The resulting conclusion is that environmental and green bonds have a broader meaning than climate bonds. The latter ones concentrate only on investments connected with weakening or adjusting to climate changes, whereas green and environmental bonds finance all broadly understood pro-environmental actions, so those concerning climate as well.

In publication of the World Bank and the Climate Bond Initiative green bonds are defined as an instrument of collecting capital to fund projects of environmental protection and to counteract climate changes [The World Bank: 23; Climate Bond Initiative, access 8.01.2020]. Such a broad approach to the essence of this category of debt securities enables to combine two aspects, the environmental and climate one, while becoming at the same time, a distinctive feature of green bonds compared to all other types of bonds.

The International Capital Market Association (ICMA) distinguishes four types of green bonds [International Capital Market Association, Green Bond Principles 2018, access 8.01.2020]:

- Standard Green Use of Proceeds Bond - a debt security with recourse towards insurer;

- Green Revenue Bond - a debt security without recourse towards insurer, in which a credit risk is connected with declared cash flows, charges, taxes, etc., exceeds from which go to related or unrelated ecological projects;

- Green Project Bond - issued for the needs of one or many ecological projects, in which an investor is directly exposed to project-related risk; with recourse towards an insurer or without that right;

- Green Securitized Bond - a bond that is secured by one or more specific ecological projects, including mortgage bonds, securities with ABS, mortgage bonds (MBS) and other structures. The basic source of payment are cash flows from assets.

The ICMA prepared a document concerning an issue of green bonds (Green Bond Principles - GBP) that is a set of guidelines in terms of transparency, disclosure and reporting of issuance and trading of the instrument whose role is to promote market coherence. The purpose of GBP is to improve access to information for market players and to encourage them to finance green projects through green bond issue. The document is to help issuers in the process of transformation of business models into more ecologically sustainable ones [International Capital Market Association, Green Bond Principles 2018: 1, access 8.01.2020].

Bond purchasers can be natural persons, enterprises and institutional investors (pension funds, hedging funds, insurance companies, asset managers, investment companies, investment funds, life insurance funds, state funds). The main investors of green bonds are investment funds whose development 
strategy takes into account investments from sustainable development group. Funds investing only in green bonds were created by big financial groups such as insurance company AXA, regional consortium SPP, Japanese group Nikko, investment management companies Blackrock, Calvert, Shelton and State Street [Brzozowska 2017: 74].

\section{GREEN BOND MARKET}

January 2007 saw an announcement of the document of the Commission to the European Council and the European Parliament entitled European Energy Policy. The document contained three principles: counteracting climate changes, reducing the EU vulnerability to impact of external factors resulting from dependency on import of hydrocarbons as well as supporting employment and economic growth, which was to guarantee safety of energy supply at reasonable prices. Considering the three principles the Commission set a strategic goal designed to reduce at least $20 \%$ of greenhouse gases compared to the level of 1990, whose achievement was to take place through improvement of energy efficiency of products, buildings and services; reducing energy intensity of production and distribution of energy; reducing impact of transport on energy consumption as well as facilitation of access to financing and actions conducive to implementation of investments in the specified areas [Europejska polityka..., 2007: 5].

The response to the document was an issue of green bonds by the European Investment Bank (EBI) in 2007 with the value of EUR 600 million. The aim of the issue was to finance projects connected with renewable energy (wind, water, solar, geothermal) and energy efficiency (local heating, cogeneration, insulation of buildings, reducing energy losses in its distribution networks) [Pawłowski 2017: 220]. One year later, the World Bank issued the first fixed interest bond with a green label. Year by year a growing interest in that instrument has been observed. Nowadays, a group of issuers comprises enterprises, banks, local government units, and over the last three years also some states have decided to join.

In 2018 the total value of global green bond market amounted to USD 167.3 billion, exceeding by 3\% a value from 2017 that amounted to USD 162.1 billion.

In 2018 capitals gathered as a result of the issue were most often earmarked to finance ventures from three areas: renewable energy (52\%), energy efficiency of buildings (13\%) as well as low-emission transport (11\%). Respectively $4 \%$ and $5 \%$ were invested in waste management and sustainable water management. 


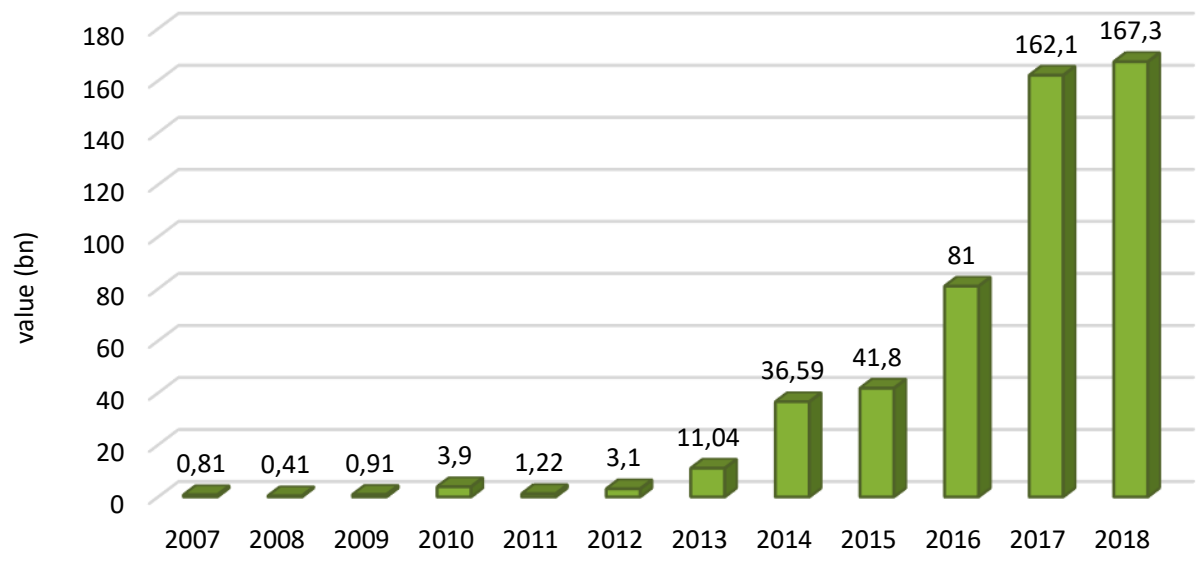

Figure 1. Global value of green bonds between 2007-2018 (in USD billion)

Source: own study based on Green Bond Highlights ..., access 20.01.2020.

Between 2017-2018 there was a growth in financing projects connected with sustainable land use that in 2018 amounted to 10\%. The remaining 5\% were allocated to broadly understood industrial projects and some connected with building adaptation [Green Bonds: The State..., access 20.01.2020]. The fact that deserves a positive assessment is that more than a half of proceeds from green bonds were allocated to energy projects to reduce emission of greenhouse gases. Actions of that kind deserve special recognition in the context of works conducted by the European Commission on implementation of the program called The European Green New Deal [access 20.01.2020]. Implementation of the document was preceded by an adoption in December 2019 the major objective concerning climate neutrality.

The biggest issuer in 2018 was the sector of financial institutions of one-fourth share in the market value. The other issues were conducted by non-financial enterprises (20\%), public sector (13\%), non-governmental institutions (10\%) and local governments $(6 \%)$. The remaining a few-percent share belonged to lending institutions. 


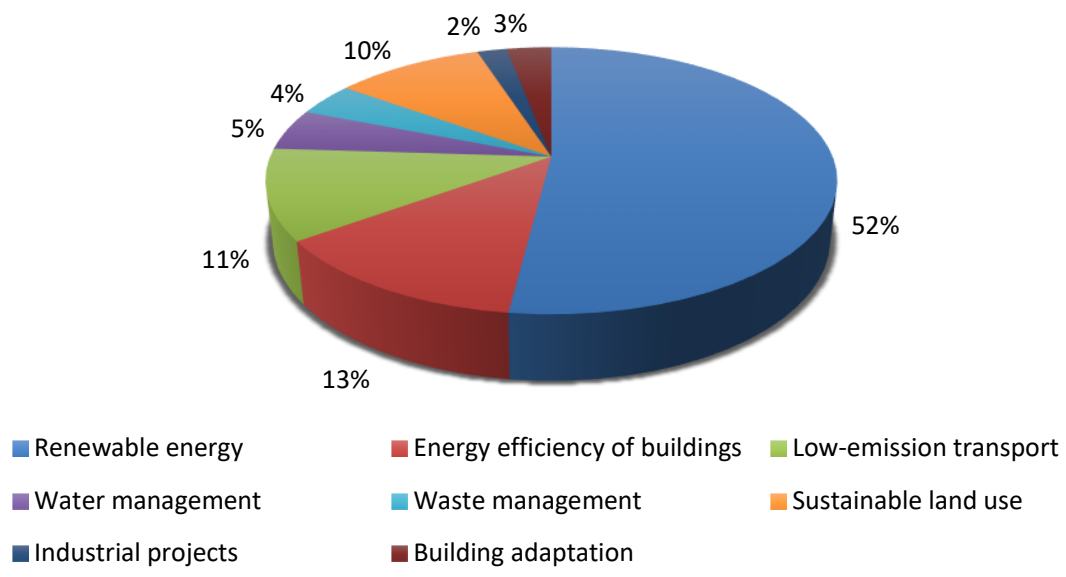

Figure 2. Structure of projects funded by green bonds in 2018

Source: own study based on Green Bonds: The State..., access 20.01.2020.

The Climate Bonds Initiative presented the ranking of ten biggest countries issuing green bonds in 2018 (Table 1).

Table 1. Ranking of countries-issuers of green bonds in 2018

\begin{tabular}{|l|c|c|}
\hline \multicolumn{1}{|c|}{ Country } & Issuance USD bn & Issuance deals \\
\hline USA & 34.1 & 1,159 \\
\hline France & 14.2 & 20 \\
\hline Germany & 7.6 & 19 \\
\hline Netherlands & 7.4 & 8 \\
\hline Belgium & 6.3 & 3 \\
\hline Sweden & 6.1 & 58 \\
\hline Spain & 5.8 & 10 \\
\hline Canada & 4.3 & 9 \\
\hline Australia & 4.2 & 9 \\
\hline Japan & 4.1 & 29 \\
\hline
\end{tabular}

Source: Green Bonds: The State ...: 10, access 20.01.2020.

Three countries: the US, France and Germany altogether in 2018 placed issues of USD 55.9 billion in green capital market, which accounted for $33 \%$ of the whole market. 
What is worth noting here is the appearance of green bonds issued by governments. In 2016 the first issue was made by the Polish government and its value amounted to EUR 750 million. The Climate Bonds Initiative in the report for 2018 indicates a growth of pace of governmental issuance of green bonds. The value of this market segment amounted to USD 17.5 billion reaching $10.5 \%$ share in the market compared to 7\% share in 2017. Debut green bonds came from Belgium, Ireland, Indonesia, Lithuania, the Republic of Seychelles, Poland and double issue from France.

The development of this market segment clearly indicates that the authorities look for new, innovative instruments of financing pro-environmental programs. Following new programs, some new ways of funding must appear and one of them are green bonds.

Governments of states that recognize the seriousness of situation concerning climate changes, adjust their internal actions to the global trend, both on a program and financial level.

\section{CHARACTERISTICS OF GREEN BONDS ISSUED IN POLAND}

On December 20, 2016 the Polish government issued an inaugural green bond, becoming thus a pioneer in governmental green capital market. Initially the government planned to issue bonds of the value of EUR 500 million. According to the accepted standard of emission to foreign markets, preparation for issuance of governmental green bonds was preceded by the so-called roadshow i.e. an issuer's meeting with potential investors. As a result of an initial market survey and higher demand for securities, a decision concerning an increase in the value of issuance to EUR 750 million was made [Green Bond Framework. Second Party ..., 2016: 3]. The issuance of bonds was preceded by preparing a document Green Bond Framework by the former Ministry of Development and Finance [Green Bond Framework, The State Treasury..., 2016: 2-3, access 21.01.2020], in which it was determined what projects are to be funded by green bonds, mechanism of funding, government agencies responsible for project qualification and financing as well as projects excluded from funding. The purpose of the issuance was described as refinancing or financing in the whole or part, of projects positively influencing the environment, promoting transition to low-emission economy, resistant to climate changes, including climate mitigation and its adjustment to observed changes. The areas qualified for green bond funding are presented in Table 2. 
Table 2. Projects funded by green bonds in Poland

\begin{tabular}{|l|l|l|}
\hline \multicolumn{1}{|c|}{ Sector } & \multicolumn{1}{|c|}{ Funding mechanism } & \multicolumn{1}{|c|}{$\begin{array}{c}\text { Additional Government Agency involved } \\
\text { in funding of these Eligible Sectors }\end{array}$} \\
\hline Renewable Energy & $\begin{array}{l}\text { budget allocation } \\
\text { - including excise tax } \\
\text { exemptions }\end{array}$ & $\begin{array}{l}\text { Ministry of Finance - Agency of } \\
\text { Restructuring and Modernization of } \\
\text { Agriculture }\end{array}$ \\
\hline $\begin{array}{l}\text { Sustainable } \\
\text { Agricultural } \\
\text { Operations }\end{array}$ & subsidies & $\begin{array}{l}\text { Ministry of Finance - Ministry of } \\
\text { Agriculture and Rural Development } \\
\text { - Agency of Restructuring and } \\
\text { Modernization of Agriculture - farmers }\end{array}$ \\
\hline Afforestation & subsidies & $\begin{array}{l}\text { Ministry of Finance - local governments } \\
- \text { forest owners }\end{array}$ \\
\hline National Parks & subsidies & $\begin{array}{l}\text { Ministry of Finance - Ministry of } \\
\text { Environment - National Parks }\end{array}$ \\
\hline Reclamation of Heaps & subsidies & SPV \\
\hline Clean Transportation & subsidies & Ministry of Infrastructure \\
\hline
\end{tabular}

Source: Green Bond Framework, The State Treasury..., 2016: 6, access 21.01.2020.

Projects excluded from financing comprised [Green Bond Framework, The State Treasury..., 2016: 3, access 21.01.2020]:

- burning of fossil fuel for power generation and transportation (in the form of rolling stock),

- rail infrastructure dedicated for transportation of fossil fuels,

- nuclear power generation,

- palm oil operations,

- production / provision of weapons / alcohol / gambling / adult entertainment,

- large scale hydro projects - including technology and equipment (i.e. projects that generate greater than $20 \mathrm{MW}$ of electricity),

- transmission infrastructure and systems where $25 \%$ or more of electricity transmitted to the grid is fossil-fuel-generated,

- use of biomass for cogeneration in coal plants.

Geographically, the Polish issue of green bonds was covered by investors from Germany and Austria (27\%), Benelux countries (17\%), Great Britain and Ireland (16\%), Nordic countries (15\%), France (13\%), Poland (7\%) and 5\% from the other countries. From the subjective perspective, green bonds were purchased predominantly by financial institutions, i.e. asset management institutions (49\%), banks (22\%), pension funds and insurance companies (16\%), central banks and public institutions (12\%) as well as remining investors (1\%) [Green Bond Report on the Use of Proceeds, Poland's Green Bond EUR 5-year...: 5, access 21.01.2020] (Figure 3). Issued bonds became viable at the level of $0.634 \%$, bearing a fixed coupon of $0.5 \%$. Securities are listed on the Luxemburg stock exchange on the Luxemburg Green Exchange platform dedicated to green instruments. 


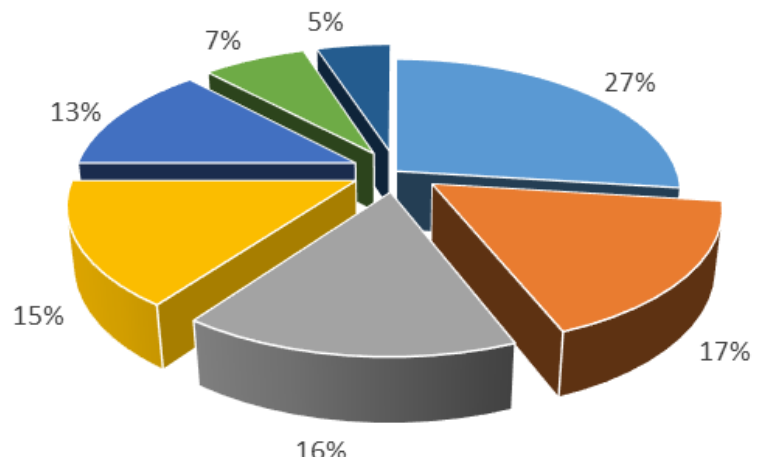

$\begin{array}{ll}\text { - Germany/ Austria }=\text { Benelux } & \text { - UK//reland } \\ \text { - France } & \text { - Poland }\end{array}$

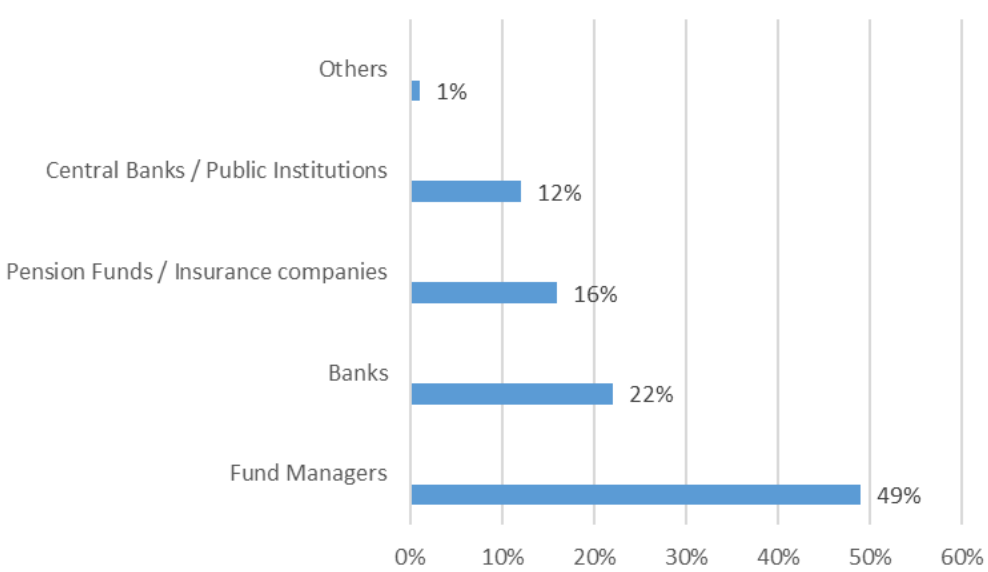

Figure 3. Geographical and subjective structure of investors of the first issuance of green bonds in Poland in 2016

Source: Green Bond Report on the Use of Proceeds, Poland's Green Bond EUR 5-year...: 5, access 21.01.2020.

According to standards, one year after the issuance the Ministry of Finance published a report concerning the use of capital from issuance of green bonds. As of October 17, 2017 an amount of EUR 745.1 million was spent, which means that proceeds from bonds were used in $80.6 \%$. The proceeds financed projects whose implementation took place between 2014-2016. The remaining $19.4 \%$ were allocated to projects initiated in the first quarter of 2017 [Green Bond Report on the Use of Proceeds, Poland's Green Bond EUR 5-year...: 10, access 21.01.2020]. 
As the report states, the biggest amount of funds was earmarked for sustainable agriculture EUR 292.1 million, low-emission transport EUR 241.3 million, renewable energy EUR 155.2 million, national parks EUR 35.4 million, forestation EUR 21.0 million, re-cultivating of heaps EUR 0.02 million.

After the success of the first issuance, the Polish government decided to conduct the second one that took place on February 7, 2018. Eight-year instruments were issued with the maturity in August 2026. Similarly, as in the first issuance, demand for securities exceeded supply, which in consequence, induced the government to raise a planned amount from EUR 500 million to EUR 1 million. Favorable valuation conditions were achieved: bond yield was at the level of $1.153 \%$, with an annual coupon of $1.125 \%$. From geographical perspective, investors were mainly from Europe, but there were also buyers from the Middle East and the United States. Financial institutions were a prevailing group among the investors (Table 3).

Table 3. Geographical and subjective structure of investors of the second issuance of green bonds in Poland

\begin{tabular}{|c|c|}
\hline \multicolumn{2}{|c|}{ Geographical structure } \\
\hline Investor & Share $(\%)$ \\
\hline France & 23.5 \\
\hline Germany & 19.0 \\
\hline UK & 13.9 \\
\hline Poland & 9.6 \\
\hline Switzerland & 5.0 \\
\hline Scandinavia & 4.8 \\
\hline Austria & 3.9 \\
\hline Benelux & 1.9 \\
\hline Other Europe & 8.1 \\
\hline USA & 3.5 \\
\hline Middle East & 2.0 \\
\hline Others & 4.9 \\
\hline \multicolumn{2}{|c|}{ Subjective structure } \\
\hline Fund Managers & 66.6 \\
\hline Banks & 15.9 \\
\hline Central Banks/Public Institutions & 9.2 \\
\hline Pension Funds/Insurance Companies & 7.8 \\
\hline Hedge Funds & 0.3 \\
\hline Others & 0.2 \\
\hline
\end{tabular}

Source: Green Bond Report on the Use of Proceeds Poland's 8-year...: 4, access 21.01.2020. 
Until November 2018 the amount of EUR 997.76 million was spent, from which $77 \%$ was earmarked for projects connected with low-emission transport (EUR 767.9 million). Subsequently, funds were allocated for sustainable agriculture EUR 84.1 million, renewable energy sources EUR 71.7 million, national parks EUR 54.1 million, forestation EUR 19.8 million and re-cultivating of heaps EUR 0.2 million [Mosionek-Szweda and Szmelter 2018: 217].

The list of parameters of two issuances of Polish green bonds is presented in Table 4.

Table 4. List of parameters of issuance of Polish green bonds between 2016 and 2018

\begin{tabular}{|l|l|l|}
\hline \multicolumn{1}{|c|}{ Parameter } & \multicolumn{1}{c|}{2016} & \multicolumn{1}{c|}{2018} \\
\hline Pricing date & December 12, 2016 & January 31, 2018 \\
\hline Settlement date & December 20, 2016 & February 7, 2018 \\
\hline Maturity & December 20, 2021 & August 7, 2026 \\
\hline Size (nominal value) & EUR 750 m & EUR 1 bn \\
\hline Bond proceeds & EUR 745.1 m & EUR 997.76 m \\
\hline Tenor & 5 years & 8 years \\
\hline Coupon & $0.5 \%$ & $1.125 \%$ \\
\hline Re-offer yield & $0.634 \%$ & $1.153 \%$ \\
\hline
\end{tabular}

Source: Green Bond Report on the Use of Proceeds, Poland's Green Bond EUR 5-year...: 10; Green Bond Report on the Use of Proceeds Poland's 8-year...: 4, access 21.01.2020.

The actions undertaken by the Polish government aiming at initiating a new instrument of financing pro-environmental activities, such as green bonds, were positively assessed by international institutions. The result of this approval were awards won for the first issuance: the Green Bonds Pioneer Awards granted by the authorities of the City together with two organizations: the International Capital Market Association (ICMA) and the Climate Bonds Initiative (CBI).

The issuance of green bonds contributed to diversification of sources of financing lending needs of the state budget while facilitating diversification of investor base at the same time, potentially decreasing exposure to fluctuations in demand for bonds. Placing the issuance of increased value not only leads to a broader scale of financing, but also - what is equally important - to reduction of costs of obtaining capital (economies of scale). A relatively short period of functioning of green bond market is related to a lack of appropriate regulations that are an instrument of protecting market players as well as the basis of its stable development. It is hard to explicitly determine the value of green bonds measured with the scale of efficiency of pro-environmental projects funded by the issuance of the described securities [Green Bonds Mobilizing...: 11, access 20.01.2020]. 


\section{CONCLUSION}

In recent years both international and national institutions have been undertaking a series of initiatives to protect the environment. There are lots of agreements and climate programs that require those in power to find new ways of financing pro-environmental projects. Challenges facing global decision-makers connected with climate changes and a scale of environmental pollution cause that it is necessary, or even indispensable, to use all available sources of finance.

Green bond market is one of the youngest segments of capital market and is a response to a need for capital financing environmental protection programs. Current experience shows that such an instrument is gaining popularity. Every year a value of issuance, a number of issuers increase and the market structure expands. The group of international institutions, enterprises was enlarged by local authorities and governments. Poland as the first country issued green debt securities of treasury nature, becoming thus the pioneer in the market. The structure of issuance received recognition of international bodies, which translated into an interest in this security, a growth in demand for the instrument, and as a result, international awards. A growing number of domestic business entities, banks and local government units, consider issuance of green bonds recognizing a huge financial potential in this new instrument in the context of initiating new pro-environmental investments. Therefore, the hypothesis stated at the beginning of the discussion has been verified positively.

The dynamics of development of global green bond market, including green issuance in Poland, will be closely related to a degree of accountability of all entities assuming growing responsibility for the environment, in which we and future generations will have to live and breathe.

\section{BIBLIOGRAPHY}

Banga J., 2019, The green bond market: A potential source of climate finance for developing countries, „Journal of Sustainable Finance \& Investment”, vol. 9, no. 1.

Brzozowska K., 2017, Idea zrównoważonego rozwoju na rynku obligacji, „Prace Naukowe Uniwersytetu Ekonomicznego we Wrocławiu", no. 478.

Climate Bond Initiative, Sector Criteria Available for Certification, https://www.climatebonds.net/standard/available.

Europejska polityka energetyczna, 2007, Komisja Europejska, KOM(2007) 1 wersja ostateczna, Bruksela.

Gatti S., Florio A., 2018, Issue Spread Determinants in the Green Bond Market: The Role of Second Party Reviews and of the Green Bond Priciples [w:] S. Boubaker, D. Cumming, D.K. Nguyen (eds.), Research Handbook of Finance and Sustainability, Edward Elgar Publishing, Northampton. 
Green Bond Highlights, Climate Bond Initiative,

https://www.climatebonds.net/files/reports/2018_green_bond_market_highlights.pdf

Green Bonds: The State of the Market 2018, Climate Bonds Initiative, https://www.climatebonds.net/files/reports/cbi_gbm_final_032019_web.pdf.

Green Bond Framework. Second Party Opinion by Sustainalytics, 2016, State Treasury of the Republic of Poland Represented by the Minister of Development and Finance, 5th December.

Green Bond Framework, 2016, The State Treasury of the Republic of Poland, Represented by the Minister of Development and Finance, 5th December.

file:///C:/Users/user/Downloads/Green_Bond_Framework\%20(1).pdf.

Green Bonds Mobilizing the Debt Capital Markets for a Low-Carbon Transition. Policy Perspectives, 2015, OECD, December, https://www.oecd.org/environment/cc/Green\% 20bonds\%20PP $\% 20 \% 5 \mathrm{Bf} 3 \% 5 \mathrm{D} \% 20 \% 5 \mathrm{Blr} \% 5 \mathrm{D}$.pdf.

Green Bond Report on the Use of Proceeds, Poland's Green Bond EUR 5-year Maturing on 20 December 2021. Ministry of Finance Public Debt Department,

file:///C:/Users/user/Downloads/Green_Bond_Report_on_the_Use_of_Proceeds\%20(1).pdf.

Green Bond Report on the Use of Proceeds, Poland's 8-year EUR Green Bond Maturing on August 7, 2026, Ministry of Finance Public Debt Department, file:///C:/Users/user/Downloads/Green_Bond_Report_on_the_Use_of_Proceeds_2_emisja\% 20(2).pdf.

International Capital Market Association, Green Bond Principles 2017, file:///C:/Users/user/Downloads/Polish\%20GPB_2017\%2006\%20v2.pdf.

International Capital Market Association, Green Bond Principles 2018, https://www.icmagroup.org/assets/documents/Regulatory/GreenBonds/Translations/2018/Polish-GBP2018-06.pdf.

Kaminker Ch., Stewart F., 2012, The Role of Institutional Investors in Financing Clean Energy, OECD Working Papers on Finance, Insurance and Private Pensions, No. 23, OECD Publishing, http://www.oecd.org/pensions/WP_23_TheRoleOfInstitutionalInvestorsInFinancingCleanEn ergy.pdf.

Kerste M., Rosenboom N., Sikken B.J., Weda J., 2011, Financing Sustainability: Insights for Investors, Corporate Executives, and Policymakers, Amsterdam, VU University Press.

Kidney S., Boulle B., 2015, The Opportunity for Bonds to Address the Climate Finance Challenge, [w:] K. Wendt (ed.), Responsible Investment Banking: Risk Management Frameworks, Sustainable Financial Innovations and Softlaw Standards, Springer International Publishing Switzerland.

Laskowska A., 2019, Zielona obligacja skarbowa jako perspektywiczny instrument rynku dlugu, „Studia Ekonomiczne”, no. 382.

Mosionek-Schweda M., Szmelter M., 2018, Zielone obligacje - nowy instrument finansowania inwestycji polskiego rząu, „Prace Naukowe Uniwersytetu Ekonomicznego we Wrocławiu”, no. 532.

Nordic Perspectives on Carbon Market Mechanisms, 2011, Copenhagen, Nordic Council of Ministers.

Pawłowski M., 2017, Zielone obligacje rzadowe, „Ekonomiczne Problemy Usług”, no. 4. DOI: 10.18276/epu.2017.129-18.

Pawłowski M., 2019, Finansowanie transportu zrównoważonego na rynku obligacji, „Studia Ekonomiczne. Zeszyty Naukowe Uniwersytetu Ekonomicznego w Katowicach”, no. 382.

The European Green Deal, Komisja Europejska, Bruksela, 11.12.2019 COM(2019) 640 final, https://ec.europa.eu/info/sites/info/files/european-green-deal-communication_en.pdf.

The World Bank, What are green bonds?, http://documents.worldbank.org/curated/en/400251468187810398/pdf/99662-REVISEDWB-Green-Bond-Box393208B-PUBLIC.pdf. 
Więckowska M., 2013, Stan i perspektywy rozwoju rynku obligacji klimatycznych, „Zeszyty Naukowe Uniwersytetu Szczecińskiego nr 766: Finanse, Rynki finansowe, Ubezpieczenia”, no. 62.

Wiśniewski M., Zieliński J., 2019, Green Bonds as an Innovative Sovereign Financial Instrument, „Ekonomia i Prawo”, vol. 18(1).

\section{ZIELONE OBLIGACJE SKARBOWE JAKO ŹRÓDŁO FINANSOWANIA ZADAŃ PROEKOLOGICZNYCH W POLSCE}

\section{Streszczenie}

Zmiany klimatyczne oraz postępujące zanieczyszczenie środowiska wymuszają podejmowanie różnorodnych działań o zasięgu globalnym. Wdrożenie i realizacja programów proekologicznych wymaga niezbędnego finansowania. W $2007 \mathrm{r}$. na rynku pojawił się nowy instrument green bond. Od tego czasu obserwuje się systematyczny i dynamiczny rozwój tego segmentu rynku kapitałowego. Rozwój dokonuje się pod względem wartości, liczby instrumentów oraz liczby emitentów. W 2016 r. na przedmiotowym rynku pojawiła się pionierska emisja zielonych obligacji skarbowych wyemitowanych przez rząd Polski.

Celem opracowania jest charakterystyka zielonych obligacji wyemitowanych przez polski rząd na finansowanie działań w obszarze ochrony środowiska na tle globalnego zielonego rynku dłużnych papierów wartościowych. W opracowaniu przyjęto hipotezę, że rozwój zielonych obligacji skarbowych w Polsce jest zdeterminowany rozwojem globalnego rynku zielonych papierów dłużnych i odpowiedzią na potrzebę intensyfikacji wydatków na programy proekologiczne.

Słowa kluczowe: zielone obligacje, inwestycje proekologiczne, zmiany klimatyczne, rynek światowy. 